\title{
Investigation into Challenges Affecting Learner Academic Performance in a Grade 10 Economics Class
}

\author{
Habasisa Molise \\ School of Education, Sol Plaatje University, 8301, Kimberly, South Africa
}

Received May 6, 2020; Revised November 5, 2020; Accepted November19, 2020

\section{Cite This Paper in the following Citation Styles}

(a): [1] Habasisa Molise, "Investigation into Challenges Affecting Learner Academic Performance in a Grade 10 Economics Class," Universal Journal of Educational Research, Vol. 8, No. 12A, pp. 7211 - 7217, 2020. DOI: 10.13189/ujer.2020.082502.

(b): Habasisa Molise (2020). Investigation into Challenges Affecting Learner Academic Performance in a Grade 10 Economics Class. Universal Journal of Educational Research, 8(12A), 7211 - 7217. DOI: 10.13189/ujer.2020.082502.

Copyright@2020 by authors, all rights reserved. Authors agree that this article remains permanently open access under the terms of the Creative Commons Attribution License 4.0 International License

\begin{abstract}
This paper investigated challenges affecting learners' academic performance in a Grade 10 economics class. Studies confirm that economics, as a subject, deals with real-life issues, and it needs to be taught such a way that learners can find connection between the content they learn in the class and prior-learning experiences. The study was qualitative, with 30 participants selected from one rural school in the Thabo Mofutsanyane education district. Focus group interviews were used to gather in-depth information regarding the challenges affecting learner academic performance in economics. The data were then analysed and various themes were identified responding to the research question. Finally, the study revealed the following findings: teachers and learners have to be motivated continuously; parents could assist in monitoring learners' work, and professional development workshops should be made available for teachers. The findings suggest that continuous professional development opportunities and support should be given to economics teachers to ensure quality teaching. The teaching and learning of economics should incorporate learners' real-life experiences in order to enhance their understanding on the content learnt in the class through the use of learner-centred strategies.
\end{abstract}

Keywords Academic Performance, Focus Group Interviews, Critical Emancipatory Research, Learner-centred Methods, Participatory Action Research, Teaching and Learning

\section{Introduction}

Rural schools continue to face several challenges that affect learners' academic performance. The challenge of poor academic performance is "created by a host of education-related factors, such as a lack of resources and learning materials, unskilled and demotivated teachers, and parents" who find it difficult to be involved in the education of their children [1,2]. This challenge is evidenced by unwillingness on the part of learners to "participate in class, poor class attendance, failure to submit written tasks, and poor academic performance in their homework, tests, and examinations" [3,4]. The problem of poor academic performance in economics is not only applicable to South Africa, but is experienced worldwide. A study conducted by Akpanobong, Akpan, and Ekpedeme [5] into learners' academic performance found that teachers are still using their indigenous home languages (not English) as language of teaching and learning, for teaching, which compromises learners understanding of economics content [2]. This finding is supported by Adedoyin [6] and Molise [7], who contend that over-reliance on learners' home language makes it difficult for the learners to interact with the content because they are expected to present their answers in English when they are assessed. This practice may be attributable to teachers' lack of content knowledge [8]. These authors argue that, because of lack of content knowledge, teachers end up not teaching for quality in their lessons, and learners end up not performing well in the subject academically. A study by Reche, Bundi, 
Riungu, and Mbungua [9] reports that the unavailability of instructional material is a hindrance that hampers the effectiveness of teachers' lessons. In contrast, the availability of teaching resources makes it possible for teachers to discharge their responsibility effectively. I argue that the problem of inadequate teaching resources, such as textbooks and exercise books, compromise quality teaching and learning [10] and makes the learning of subjects such as economics an abstract exercise for learners [11]. This finding is supported by Muraya and Kimamo [12], who suggest that, if learners do not have sufficient instructional materials, they tend to be passive during lessons and remain passive. Wadesango [13] found that some teachers complain about being excluded from meetings where subject allocations are done, and that they do not even have a say regarding the selection of textbooks for their learners. Molise and Hlalele [14] support the claim that instructional resources are not always available, and if they are available, the materials are not suitable for self-study. Kearney and Perkins [15] found that teachers' lack of motivation and negative attitudes towards the subject renders them incompetent to teach the subject with passion. This claim is enforced by Tahir, Wahjoedi, Widjaja and Wahyono [16], who assert that context-based activities should be used "as a way of practicing economic learning in order to provide a new atmosphere for increased motivation and achievement of learners in the learning process". Ifamuyiwa and Akinsola [17] contend that there is an urgent need for continuous motivation of teachers, by allowing them to be part of decisions that are taken regarding curriculum delivery. Giving the teachers voices will contribute to restoring harmonious relation between all stakeholders in the school. Reche et al. [9] found that offering rewards for teachers can enhance teachers' motivation and fuel competition among the teachers who are keen for recognition of their work. Accordingly, Asikhia [18] propounds the involvement of parents to help with monitoring their children's work and assisting with discipline at the school. I argue that, if learner discipline is taken for granted, teachers will remain demotivated and will face challenges in delivering their lessons as planned. Berthelsen and Walker [19] report that the involvement of parents in decisions regarding their children enables them to assist the teachers with unruly learners and help to identify other parents who are not keen to work with the school. Chowa, Ansong, and Osel-Akoto [20] suggest that talking to learners about what they learn at school is significantly and positively associated with good academic performance in economics. The findings of Mannatlhoko and Mangope [21] support this view, by reporting that few parents are capacitated on the roles they can play in contributing positively to school activities. They send their children to school only to learn, and expect the teachers to perform miracles to ensure that the learners pass. I argue that parents could assist with general cleaning of school premises, gardening and making donations, to help the school buy instructional materials that may be unavailable. In Nojaja's [22] view, involving parents in school activities will enlighten them about the different roles they can play to assist with the inherent challenges schools experience [23].

\section{Problem Statement}

Poor academic performance in economics remains a challenge facing South African schools [24-26]. According to Van Wyk [2], the subject of economics "deals with issues learners are confronted with daily, and it should, therefore, be taught in such a manner that learners can easily relate what they learn in class with realities outside the classroom - which is, unfortunately, not always the case. It is rather taught as a dry, analytical subject that is difficult for learners to relate to everyday life”. Ongeri [27] adds that teaching economics requires that the subject be made real to the learners to avoid memorization of the content without understanding. This paper sought to investigate the challenges of poor academic performance in a Grade 10 economics class.

\section{Theoretical Framework}

The researcher positioned this paper using critical emancipatory research (CER) as the theoretical lens, because of its ability to advocate for peace, hope, equality, team spirit, and social justice [28]. CER, as used in this paper, is committed to enabling teachers and learners to question the injustices related to instructional practices prevalent in economics classrooms [29], while liberating them and meeting their needs for real life and self-consciousness [30]. The CER approach can be regarded as an emancipatory experience, in that it provides space for free contribution of ideas, cordial relationships, tolerance of individual ideas, common consensus, love and hope [31]. Similarly, Akinsolu [32] contends that CER builds relationships and individual consciousness between learners and teachers and enables them to collectively source solutions prevalent in the school. The researcher argues, furthermore, that CER forms the basis of a democratic society and it is for this reason that I perceive it to provide a foundation for analyzing and understanding the adversities that disempower the teachers and learners, and prevent them from teaching and learning the economics content effectively. Teaching for social justice in the economics classroom contributes to shaping learners' academic performance, helping them to be better prepared to relate the economic theory they learn in class to real-life situations. In this way, teaching and learning economics is 
not seen as a mimetic activity, but rather a way of infusing economic skills that enable learners to learn meaningfully. According to Riggs and Langhout [33], CER helps to defuse power that exists between the researcher and co-researchers, by creating space for them (the co-researchers) to express how they believe economics content resonates with them, so that they can participate on an equal basis [14].

CER enabled the researcher to initiate focus group meetings that served to create space and opportunity for participants to use their own language to create an unthreatening environment, while encouraging them to speak freely without fear or intimidation [30]. My role, as the researcher, throughout the information sessions [34] was to facilitate meetings for the teaching and learning of economics, by stimulating emancipatory conversations that were audio-recorded for purposes of analysis at a later stage.

\section{Method}

The researcher followed participatory action research (PAR), a research approach that advocates that power relations must be addressed at each stage of the research process to ensure positive change in problematic contexts [31,35]. In line with this paradigm, participants from various social structures were selected to be part of this research, to investigate the challenges affecting learners' academic performance in a Grade 10 economics class. This paper reports on a 24-month interactive engagement with the school community, with a focus on challenges affecting learners' academic performance in a Grade 10 economics class. The interaction with the school community was tested in one school in the Thabo Mofutsanyana district of the Free State province. For anonymity, the school was given the pseudonym Atlehang Secondary School (490 learners). The data were generated through PAR, in which 30 participants participated, among whom school governing bodies, subject advisors, religious leaders, municipality officials, educators, learners, and principals. The researcher chose this approach to research because it is emancipatory, critical, or transformative, and values social justice as an underpinning factor to guide relations with the school contexts [36]. To ensure the success of PAR as an approach, the researcher asked the participants to contribute freely and negate any form of power deferential, through understanding that the goal of the research is not to expose political and educational challenges, but rather to work together to find solutions to their challenges. Since the researcher and participants were equally involved in the process, they shared responsibility for the outcome of the research endeavour. In other words, participation, research, and action were of major importance in the partnership. PAR was mainly about relationships between the stakeholders involved in the research process, and the use of research as a tool for action $[37,38]$. Thus, collective action was taken to bring about long-term solutions, in this instance, putting an end to academic underperformance, and adopting solutions to their problems. PAR, thus, created a democratic system that enabled relevant stakeholders' active involvement in finding solutions to challenges relating to academic performance $[39,40]$.

\subsection{Data Collection}

The study sought to answer the following research question: What are the challenges affecting learners' academic performance in a Grade 10 economics classroom? The responses to this question enabled the researcher to distil several themes for discussion. These themes emanated from subjecting the generated data to the analytical lens proposed by Laws, Harper and Marcus [41], which involved the following steps:

Step 1: Reading and rereading all the collected data: the data from both interviews and questionnaires were read and reread to obtain the views of the participants.

Step 2: Drawing up a preliminary list of themes arising from the data: major issues and themes were identified and arranged according to the research question of the study.

Step 3: Rereading the data: this compelled the researchers to verify whether identified themes were aligned with the participants' comments, and corresponded to the research question.

Step 4: Linking the themes to quotations and notes: the themes emerging from the data were linked to various scholarly views.

Step 5: Perusing the categories of themes to interpret them: in interpreting the data, the researchers remained cognizant of the research question.

Step 6: Designing a tool to assist in discerning patterns in the data, to triangulate data during the data analysis process.

Step 7: Interpreting the data and deriving meaning: this mainly related to highlighting the research findings and arranging material according to categories premised or guided by the research question.

Data from focus group discussions were transcribed and then coded and categorized into various themes in relation to the challenges affecting learner academic performance in economics. To ensure the validity of data, member checking was done and themes were sent back to the participants to verify that the data represented what they identified as challenges that cause poor academic performance [36]. Participants signed consent forms and were assured that their identities would be protected [37] and that the information they provide would be used only for compiling this research, which makes suggestions on how challenges affecting learner academic performance 
can be tackled. Pseudonyms are used to protect the participants' identities

\section{Findings}

This section presents the findings that emerged in the form of themes, which were identified from the generated data. The themes are the continuous motivation of teachers and learners; involving parents in monitoring learners' schoolwork, and professional development workshops for teachers.

\subsection{Continuous Motivation of Learners and Teachers}

The study found a lack of motivation in teachers and learners to be a challenge. There is little accountability for engagement during lessons, and learners are not required to process information at a high level [2,17]. Lema (a learner) had this to say:

Our teachers are not motivated to teach, they always complain about their demanding yet non-paying work and claim that they want to quit teaching.

This claim was supported by Pule (learner) who explained,

I do not like teaching. I say that because of the lack of motivation and negative attitude the teachers have towards their profession, they do not teach in effective ways, nor act as role models to the learners.

The statement, "I do not like teaching", indicates that teachers do not consider teaching to be a desirable profession, and this attitude leads to a lack of motivation due to a negative attitude. Alice (teacher) qualified Pule's (learner) view, and said,

The learners I have taught earn more than I do but I have worked for more than ten years, I will not encourage my children to be teachers.

In the same vein, Siza (teacher) added,

Our efforts are not recognized, we teach even on weekends and holidays, but the government does not care about us, we are unable to pay for our children at university, because of the little salary we get.

Siza and Alice agreed that the teaching profession offered little that could benefit them; they worked hard for small salaries and their efforts were not recognized. The team helped all the co-researchers, including teachers, to understand the contribution teachers made to transforming the lives of learners. The reward was not always monetary, but sometimes uplifting the lives of those at the edge of marginalization. The participants' comments are reinforced by Asikhia [18], who explains that "declining levels of academic achievement can be attributed to the attitudes of some teachers towards their job, as reflected in poor attendance of lessons, tardiness, derogatory comments about student performance, and inadequate teaching methods".

Hlabs (teacher) had a different view of the issue, and said,

The learners disrespect us; we work under appalling situations where only learners have a say.

From Hlabs' comment, it is evident that learners are not motivated to learn. The words, "They are disrespectful", indicates that teachers face challenges related to dealing with learner behaviour at the school. The participant added, "They are the only ones who have a say", which means that school policies favour the learners, to the extent that teachers are powerless to enforce discipline at school. It can be concluded that the school was not rewarding teachers and learners for the good work they do.

\subsection{Involving Parents to Monitor Learners' Schoolwork}

The findings of the study show that parents $[42,30]$ are not allowed to question how their children should be taught. Instead, they are regarded as individuals without knowledge and information, and with little to contribute to ensure that their children succeeded academically [43]. Isaac (principal) commented that,

In my view, the school can only perform if the parents can take part in the education of their children. The parents who have children in this school do not have cooperation.

Mpho (parent) said,

They do not even bother attending parents meeting but letters are issued to inform them about meetings.

The comments by Isaac and Mpho indicate that parents still do not play an active role in the education of their children. This paper provided a foundation to encourage parents to take part in all the activities of the school. The team we established laid a foundation for them to question some of the injustices prevalent at school, which perpetuated marginalization. Mpho's comment is reinforced by Berthelsen and Walker [19], who write that, "if parents expect high levels of academic performance and commitment to schooling, the child is more likely to adopt these positive attitudes". This implies that, to improve learners' academic performance in economics, parents must have positive feelings about the school. Positive feelings encourage parents to become part of the school and to contribute in ways that will bring positive results to the school in general. Chowa et al. [20] contend that talking to children about what they learn in school is significantly and positively associated with good academic performance in economics. However, Siza (teacher) had this to say,

We give these learners homework but they don't write to them. 
Jane (teacher) interrupted and said,

The worst part is when we call their parents they do not come.

From Siza and Jane's comments, it is clear that parents do not monitor their children's schoolwork, and it is a challenge for teachers to teach effectively because they are confronted by challenges related to discipline in their classroom. Gloria (deputy principal) expressed her disappointment by saying,

I remember in a particular year calling a parent regarding the behaviour of his child, instead came a young boy claiming to be the parent.

The comment shows that teachers implement initiatives to involve and talk to parents about their children's discipline at school, but learners play hide and seek between their teachers and parents, because there are no cooperative relationships between the school and the community, or between teachers and parents. Consequently, Mpho (parent) supported Gloria's (deputy principal) comment and said,

You just reminded me, at the beginning of the year [name redacted] slapped the other learner and when I told her to call the parents she told me I should call the police.

This comment implies that parents evade their responsibility to discipline their children, and send the children to school to avoid the stress of disciplining them themselves. Judging from the parent's comment, "what should she do", it is evident that the parent had done all she could, but had failed and lost hope for the child.

This team enabled us to restore trust between the school and the community. Parents are now in a position to discipline their children, because of the alternatives suggested and implemented by the rest of the team during its information sessions. Siza (teacher) moved the discussion forward, by stating,

I am sure the parent does not know what to do anymore. Learners of today!

His comment is reinforced by Mannatlhoko and Mangope [23], in whose opinion, most parents, especially those in remote areas, are unaware that they are supposed to offer teaching assistance services at schools. Teachers indicated that parents were not cooperative in contributing to their children's learning. Similarly, Hlabs (teacher) supported Siza's (teacher) view and commented that,

I believe the presence of the parents can bring a difference in the education of their children.

Hlabs' view is reinforced in Nojaja [22], who states that involving parents in the education of their children has become a major goal of professionals, particularly those working with at-risk learners. However, a systematic collaboration between the home, the school, and the community remains a distant dream. Consequently, continuous support from the home, community, and school is a prerequisite for academic success in accounting. The conclusion that can be drawn is that the connection between school activities and those of the community is lacking and that the school exists in isolation, not as part of the community.

\subsection{Professional Development Workshops for Teachers}

The paper found that teachers do have access to professional development opportunities; however, there is a notable lack of follow-up by the district office to support teachers after once-off training sessions [11]. Follow-up at school level is not done, and department officials lacked monitoring mechanisms to ensure that schools are applying the new learner-centered approaches, as expected [38]. Siza (teacher) said,

We get developed by our LF (subject advisor) but the time for training is limited and they do not do follow-ups to check if teachers can implement.

Hlabs (teacher) supported Siza's (teacher) point of view:

You are correct, the problem is they are always in a fault-finding mission instead of supporting us, the only come towards the end of the year and fight us.

Both Hlabs and Siza's views indicate that the district is not doing enough to support teachers to face the challenges confronting their classrooms. Subject advisors are not continually visiting schools to support teachers, and that when they do, they only do so to evaluate the subject portfolios of the teachers, and fail to give support. The workshops that are organized by district officials (learning facilitators) are not beneficial, since teachers remain uncertain about how to teach their learners effectively to achieve improved academic performance in economics. Hlabs' view is reinforced by Tsotetsi [38], who reports a lack of support from the district office.

This paper concludes that lack of opportunities for professional development is caused by lack of money; learning facilitators or subject advisors, who find it difficult to travel to schools due to lack of money or having exceeded the budget.

\section{Conclusions}

This paper aimed to investigate the challenges facing learners' academic performance in economics. The paper reviewed literature from South Africa and abroad to show that the problem of poor learner performance is not only local, but is a global one. The paper also discussed CER, as the theoretical lens foregrounding the study, and reported how it helped achieve the objective of the paper. A discussion on how the PAR approach was used, was also provided. The data were generated through focus group meetings. The findings of the paper were analyzed and presented as themes emerging from the transcripts. 
Based on these findings, the paper, thus, recommends that teachers should receive continuous training on economics content knowledge. Teachers should not be allowed or expected to teach outside their majors, because it may lead to learners not being taught correctly. The school must purchase adequate instructional materials; and continuously motivate teachers and learners, to keep them fuelled and ready to embrace their teaching. This could be done by inviting motivational speakers, parents, and religious leaders to address them. Parents should be informed of meetings and be trained, so that they are knowledgeable about the roles they can play and the contribution they can make to shaping the school into a better place for learning. New teachers should be subjected to continuous professional development to improve their teaching practice.

\section{REFERENCES}

[1] Gabre H.G., Kumar G., "The Effects of Perceived Stress and Facebook on Accounting Students' Academic Performance," Accounting and Finance Research, vol. 1, no. 2, pp. 88-100, 2012.

[2] Van Wyk M., “The Use of Economics Games as a Participative Teaching Strategy to Enhance Student Learning,” Journal of Social Science, vol. 35, no. 2, pp. 125133, 2013.

[3] Agbatogun A., "Self-concept, Computer Anxiety, Gender, and Attitude Towards Interactive Computer Technologies: A Predictive Study Among Nigerian Teachers,” International Journal of Education and Development, no. 6, vol. (2), pp. 1-14, 2010.

[4] Loyens S.M.M., Kirschner P.A., Paas F., "Problem-based Learning,” in APA Educational Psychology Handbook: Application to Learning and Teaching, APA, 2011, pp. 403425.

[5] Akpanobong U.M., Akpan A., Ekpedeme P.T., "Secondary School Students: Self-concept and Their Academic Achievement in Financial Accounting," International Journal of Research Development, vol. no. 35, pp. 317-328, 2008.

[6] Adedoyin O.O., “The Impact of Teachers' In-depth Pedagogical Mathematical Content Knowledge on Academic Performance: As Perceived by Botswana Junior Secondary School Pupils,” European Journal of Educational Studies, vol. 3, no. 2, pp. 277-297, 2011.

[7] Molise H.V. "The Use of a Case Study Approach to Improve Learner Academic Performance in Economics," Unpublished Master's dissertation, University of the Free State, 2015.

[8] Van Wyk M., Alexander G. "Do Teaching Methods Presented by the National Council on Economics Education (USA) Enhance Trainers' Learning Capacity in economics education? A South African Perspective,” Journal of Social Science, vol. 23, no. 3, pp. 159-169, 2010.
[9] Reche G.N., Bundi T.K., Riungu J.N., Mbungua Z.K., "Factors contributing to poor performance in Kenya Certificate of Primary Education in public day primary schools in Mwimbi Division, Maara District, Kenya," International Journal of Humanities and Social Science, vol. 2, no. 5, pp. 127-133, 2012.

[10] Kimani G.N., Kara A.M., Njagi L.W., "Teacher Factors Influencing Students' Academic Achievement in Secondary Schools," International Journal of Education and Research, vol. 1, no. 3, pp. 1-14, 2013.

[11] Karue N., Amukowa, W., Analysis of Factors that Lead to Poor Performance in Kenya Certificate of Secondary Examination in Embu District in Kenya," International Journal of Social Sciences, vol. 13, no. 1, pp. 92-108, 2013.

[12] Muraya D.N., Kimamo G., "The Effects of cooperative Learning Approach on Biology Mean Achievement Scores of Secondary School Students," Education Research and Reviews, vol. 6, no. 12, pp. 726-745, 2011.

[13] Wadesango N., "The Extent of Teacher Participation in Decision-Making in Secondary Schools," School Leadership and Management, vol. 30, no. 3, pp. 265-284, 2010.

[14] Molise H.V., Hlalele D.J., Using a Case Study as a Teaching and Learning Strategy in the Teaching of Economics: A Literature Review," Mediterranean Journal of Social Sciences, vol. 5, no. 23, pp. 999-1008, 2014.

[15] Kearney S.P., Perkins T., “Developing Students' Capacity for Innovation, Creativity, and Critical Thinking Through Contemporary Forms of Assessment," International Conference on Education, vol. 9, pp. 1-10, 2011.

[16] Tahir M.I.T., Wahjoedi, Widjaja S.U.M., Wahyono H., "Economic Learning with a National and Local-Cultural Values Combination Strategy," Universal Journal of Educational Research, vol. 8, no. 1, pp. 225-229, 2020.

[17] Ifamuyiwa S.A., Akinsola M.K., "Improving Senior Secondary School Students' Attitudes Towards Mathematics Through Self and Cooperative-Instructional Strategies," International Journal of Mathematical Education in Science and Technology, vol. 39, no. 5, pp. 569-585, 2008.

[18] Asikhia O.A., “Students' and Teachers' Perception of the Causes of Poor Academic Performance in Ogun State Secondary Schools [Nigeria]: Implications for Counselling for National Development," European Journal of Social Sciences, vol. 13, pp. 228-242, 2010.

[19] Berthelsen D.N., Walker, S., "Parents Involvement in Their Children's Education," Australian Institute of Family Studies, vol. 79, pp. 34-41, 2010.

[20] Chowa G.A.N., Ansong D., Osel-Akoto I., "Parental Involvement and Academic Performance in Ghana," Youth-Save Research Brief 12-42, Washington University Centre for Social Development, 2012.

[21] Mannatlhoko M.C., Mangope B., "Barriers to Parental Involvement in Primary Schools: A Case of Central North Region of Botswana,” International Journal of Scientific Research in Education, vol. 6, no. 1, pp. 47-55, 2013.

[22] Nojaja J.M., “A Model for Parental Involvement in Disadvantaged South African Schools” Unpublished Ph.D. thesis, North-West University, 2009. 
[23] Awolola SA, Effect of brain-based learning strategy on students' achievement in senior secondary school mathematics in Oyo State, Nigeria. Cypriot Journal of Educational Sciences, vol. 2, pp. 91-106, 2011.

[24] Addow A.M., Abubakar A.H., Abukar M.S., "English language proficiency and academic achievement for undergraduate students in Somalia,” Educational Research International, vol. 2, no. 2, pp. 59-66, 2013.

[25] Sapire I., Reed, Y., "Collaborative design and use of open educational resources: a case study of mathematics teacher education project in South Africa," Distance Education, vol. 32, no. 2, pp. 195-211, 2011.

[26] Van der Merwe A., "Using blended learning to boost motivation and performance in introductory economics modules," South African Journal of Economics, vol. 75, no. 1, pp. 125-135, 2007.

[27] Ongeri J.D., "Poor student evaluation of teaching in economics: Critical survey of the literature,” Australasian Journal of Economics Education, vol. 6, no. 2, pp. 1-24, 2009.

[28] Mahlomaholo M.G., "Critical emancipatory research and academic identity,” Africa Education Review, vol. 6, no. 2, pp. 224-237, 2009.

[29] Moloi T.J., "Enhancing Problem-Solving Skills in a Grade 10 Mathematics Classroom by Using Indigenous Games," Unpublished Ph.D. thesis, University of the Free State, 2013.

[30] Makoelle T.M. “Exploring Teaching Practices that are Effective in Promoting Inclusion in South African Secondary Schools'” Unpublished Ph.D. thesis, University of the Free State, 2013.

[31] Tshelane M.D. "Participatory Action Research and the Construction of Academic Identity Among Postgraduate Research Students,” Journal of Transdisciplinary Research, vol. 9, no. 3, pp. 401-429, 2013.

[32] Akinsolu A.O. “Teachers' and Students' Academic Performance in Nigerian Secondary Schools: Implications for Planning,” National Institute for Educational Planning and Administration, vol. 3, no. 2, 86-103, 2010.

[33] Riggs D., Langhout R.D., "Elucidating the Power in Empowerment and Participation in Participatory Action Research: A Story About the Research Team and Elementary School Change," American Journal of Community Psychology, vol. 45, pp. 215-230, 2010.

[34] Mahlomaholo S., Netshandama V., "Post-Apartheid Organic Intellectuals and Knowledge Creation,” in Understanding Knowledge Creation. Intellectuals in Academia, the Public Spheres, and the Arts, Rodolph, 2011.

[35] Van der Velde D.L., Ogilvie D.L., "Participatory Action Research: Practical Strategies for actively Engaging and Maintaining Participation in Immigrant and Refugee Communities," Qualitative Health Research, vol.19, no. 9, pp. 127-159. 2009.

[36] Dube B., Hlalele D., "Engaging Critical Emancipatory Research as an Alternative to Mitigate School Violence in South Africa," Educational Research for Social Change, vol. 7, no. 2, pp. 74-86, 2018.

[37] Dube B., Molise H.V., "The Church and its Contributions to the Struggle to Liberate the Free State," Journal of Contemporary History, vol. 43, no. 1, pp. 160-177, 2018.

[38] Tsotetsi C.T., “The Implementation of Professional Teacher Development Policies: A Continuing Education Perspective," Unpublished Ph.D. thesis, University of the Free State, 2013.

[39] Nkoane M.M., "Critical emancipatory research for social justice and democratic citizenship," Perspectives in Education, vol. 30, no. 4, pp. 98-104, 2012.

[40] Sluys K., “Trying on and Trying Out: Participatory Action Research as a Tool for Literacy and Identity Work in Middle Grades Classrooms,” American Journal of Community Psychology, vol. 46, 139-151, 2010.

[41] Laws, S., Harper, C. \& Marcus, R. Research for Development. Sage, 2003. 